\title{
Empirical Evidence of CAPM and Fama French Three-Factor Model at Cement Industry of DSE
}

By Avijit Mallik, Mrs. Syeda Mahrufa Bashar \& Md. Sadid Uddin

Abstract- The study discusses empirical evidence on the explanatory power for cement manufacturing industries of the Dhaka Stock Exchange in light of Capital Asset Pricing Model (CAPM) and the Fama French three-factor model. For calculating the market return, both DSEX and DS30 indexes have been used. The study revealed that the Fama French three-factor model has better explanatory power compared to the CAPM model in the Dhaka Stock Exchange. Moreover, the size risk premium has a significant influence in explaining the expected return for cement industries of the Dhaka Stock Exchange for both DSEX and DS30. On the other hand, the value risk premium has significant power in explaining the expected return for cement industries in the Dhaka Stock Exchange.

Keywords: fama french, CAPM, stock market.

GJMBR-C Classification: JEL Code: F65

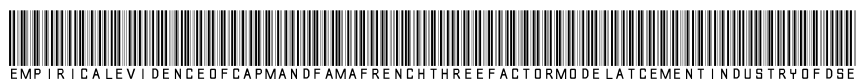

Strictly as per the compliance and regulations of:

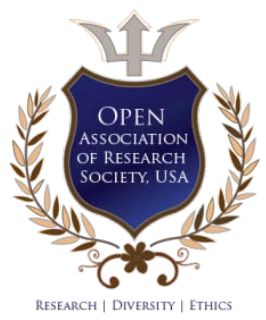

(C) 2020. Avijit Mallik, Mrs. Syeda Mahrufa Bashar \& Md. Sadid Uddin. This is a research/review paper, distributed under the terms of the Creative Commons Attribution-Noncommercial 3.0 Unported License http://creativecommons.org/licenses/by-nc/3.0/), permitting all non-commercial use, distribution, and reproduction in any medium, provided the original work is properly cited. 


\title{
Empirical Evidence of CAPM and Fama French Three-Factor Model at Cement Industry of DSE
}

\author{
Avijit Mallik ${ }^{\alpha}$, Mrs. Syeda Mahrufa Bashar ${ }^{\circ}$ \& Md. Sadid Uddin ${ }^{\circ}$
}

Abstract- The study discusses empirical evidence on the explanatory power for cement manufacturing industries of the Dhaka Stock Exchange in light of Capital Asset Pricing Model (CAPM) and the Fama French three-factor model. For calculating the market return, both DSEX and DS30 indexes have been used. The study revealed that the Fama French three-factor model has better explanatory power compared to the CAPM model in the Dhaka Stock Exchange. Moreover, the size risk premium has a significant influence in explaining the expected return for cement industries of the Dhaka Stock Exchange for both DSEX and DS30. On the other hand, the value risk premium has significant power in explaining the expected return for cement industries in the Dhaka Stock Exchange.

Keywords: fama french, CAPM, stock market.

\section{InTRODUCTION}

T he stock market plays a robust role in ensuring the economic growth of a country (Hasan and Kamil, 2014). Liquidity creation, improvement in international trade, accumulation of wealth for the investors, etc. are some of the unique features which help the analysts forecast the future development of the country (Blake, 2000). Toporowski (2000) opined that the stock market through the efficiency and profitability of firms can ensure the country's economic development. The price of the stock is of enormous concern to the investors, brokerage firms and analysts, which is the fundamental question of finance. Fundamental finance wants to know how the risk of any particular asset potentially affects the expected return of the stock. In this regard, Sharpe (1964) and Lintner (1965) developed the first model, namely 'Capital Asset Pricing Model', shortly abbreviated as CAPM.

CAPM suggests there are two very unique risks associated with any stock: one is the systematic risk, and the other one is an unsystematic risk. Systematic risk is measured by beta, while the unsystematic risk is measured through the diversification of the portfolio (Sharpe, 1964). As systematic risk can't be eliminated even by diversification, the CAPM model shows a relationship between systematic risk and the expected return of any particular stock. Several studies have been conducted which show positive evidence for the CAPM

Author a: Lecturer, Institute of Business Administration, University of Dhaka.e-mail: avijit@iba-du.edu

Author o: Associate Professor, Institute of Business Administration, University of Dhaka.e-mail: mahrufa@iba-du.edu

Author $\rho$ : Graduate Student, Institute of Business Administration, University of Dhaka. e-mail: sadiduddin@gmail.com model (Hasan and Kamil, 2014; Black, Jensen \& Scholes, 1972; Fama \& Macbeth, 1973). However, after the 1980s, several authors questioned the validity of the CAPM model, including Reiganum (1981), Fama and French (1992), etc. Reiganum (1981) didn't find any significant relationship between the risk premium and beta. On the other hand, Fama and Macbeth (1973) added extra factors in CAPM, such as size (market capitalization) and book to market ratio. These extra factors undoubtedly increased the validity and precision of the model in explaining the associated risk and return of the stock. Later on, Fama and French (1993) developed the most prominent model, which is called now Fama-French three-factor model. It includes market factor, SMB (the difference between the return of small size and large size stocks), HML (the difference between the return of the high book to market value and low book to market value stocks). The study carried out by Fama and French (1993) revealed that small-sized firms outperform big sized firms and firms with higher book to market ratios perform better than the lower book to market ratio. The combined effect can explain better the cross-sectional variation in average stock return (Hasan and Kamil, 2014).

In this paper, both CAPM and Fama French three-factor model has been applied for the cement industry in Dhaka Stock Exchange for Bangladesh. The study aims to answer if beta solely can answer the variation in stock returns. Moreover, the study tries to answer if the Fama French three-factor model can answer variation in average stock returns.

We have considered the data period 2013-2019 (August) for the constructing portfolio. There are several reasons for choosing the Bangladeshi stock market. The Fama French three-factor model has been applied mainly in Western countries including US, UK, Australia, Europe where the stock market is usually vibrant and efficient ( Sayeed et al., .2014; Fama and French, 1996; Isakov, 1999; Faff, 2001). For that, the study aims to see if the Fama French three-factor model is still an effective Bangladeshi stock market where the stock market is not that efficient compared to the developed ones.

We have used monthly closing price for conducting the study. Through the formation of four portfolios using small size, large size, value stock, growth stock, CAPM and Fama French three-factor model will be applied separately. We have used DSEX for indexing purposes. 


\section{il. Literature ReViews}

Many researchers worked on different theories to explain excess market returns after Markowitz discussed his famous Portfolio Theory. According to Markowitz, the portfolio risk is to be calculated through mean-variance of associated returns where the investors try to maximize their returns or minimize risks (Chowdhury, 2017).There's been a long debate regarding the asset pricing model on the factors of returns of a stock. Sharpe (1964) opined that there is a positive correlation with the market return for any individual stock. Both Sharpe (1964) and Lintner (1965) established Capital Asset Pricing Model (CAPM Model); since then till today CAPM Model has been widely used as a predominant theory for calculating the cost of equity and determination of asset pricing (Chowdhury, 2017). CAPM assumes that the return of any asset has a linear relationship combining both the risk-free asset and risk premium assets. The risk premium of the asset is well defined by both market risk premium and beta of the asset. In the CAPM Model, the relationship between risk and expected return is linear (Chowdhury, 2017).Precisely, the CAPM method is based on only one kind of risk factor which is a systematic risk. For measuring the dependency of the return of stock on market return, Sharpe (1964) used beta. Beta is the single risk factor to be interpreted in the CAPM model and this is the central area of discussion in the model. In short, risk-averse investors must be compensated with the excess return for additional risk associated with beta. However, many researchers questioned the validity and precision of beta (Hossan and Abedin, 2019; Novak and Petr, 2011, Mobarek and Mollah, 2005; Chowdhury and Sharmin, 2013) in the stock market of Sweden and Bangladesh respectively. Their opinion was that beta might have incomplete information regarding the stock return.

The relation between risk and return of an asset according to CAPM is shown below-

$$
E\left(R_{i}\right)=R_{f}+\beta_{i}\left[E\left(R_{M}-R_{f}\right)\right.
$$

Where,

$R_{f}=$ risk-free rate of return

$E\left(R_{M}\right)=$ expected market rate of return

$\beta_{i}=$ sensitivity of the asset's to the market return

$E\left(R_{i}\right)=$ asset's the expected rate of return

Earlier studies showed a positive relationship between the price of the asset and its associated beta (Black, Jensen and Scholes, 1962; Blume and Friend, 1973; Fama and Macbeth, 1973). However, the marginal return of the stock can little be explained by crosssectional differences in stock returns. Few studies find that beta fails to measure return premium appropriate by both small firms and high book to market equity firms
(Basu, 1977; Banz, 1981; Reinganum, 1981; Rosenberg et al., 1985; Lakonishok et al., 1994).

Though CAPM was a revolutionary model in the history of finance, many empirical studies were conducted which in turn challenged the validity of the CAPM Model itself. Later on, Fama and French (1993) developed the three-factor model by introducing size factor and book to market equity ratio along with the usual CAPM model (Hossan and Abedin, 2019). Fama French three-factor model was developed in fact for addressing the limitation of CAPM as the latter model could capture only risk factors that were deemed to be inadequate. Their study summarizes that this threefactor model can better explain the return of any particular stock compared to the existing CAPM model. Fama and French (1993) have used around 342 monthly observations of the US stock market while testing the model. After their intervention, many researchers and analysts applied this model in other markets. The key observation of Fama and French was that those firms with low market capitalization and value stocks outperform the market. In short, Fama and French added two more factors to the original CAPM equation:

$$
\begin{aligned}
R_{p t}-R_{f}=\alpha_{p t} & +\beta_{p}\left(R_{m t}-R_{f}\right)+s_{p}(S M B) \\
& +h_{p}(H M L)+\varepsilon_{p t}
\end{aligned}
$$

Where,

$R_{p t}=$ portfolio p's return at time $\mathrm{t}$

$R_{f}=$ the risk-free rate

$\alpha_{p t}=$ the excess return of portfolio $\mathrm{p}$ at time $\mathrm{t}$

$\beta_{p}=$ the co-efficient loading for the excess average returns of the market portfolio over the risk-free rate

$s_{p}=$ the co-efficient loading for the excess average returns of portfolios with small equity class over portfolios of big equity class.

$h_{p}=$ the co-efficient loading for the excess average returns of portfolios with high-book-to-market equity class over those with low-book-to-market equity class $\varepsilon_{p t}=$ the error term for portfolio $\mathrm{p}$ at time $\mathrm{t}$

In Australia, the Fama-French three-factor model was applied for the data period 1991-1999 and the result was in favor of the Fama-French three-factor model (Faff, 2001). In Malaysia, the Fama-French threefactor model showed higher returns for the small and higher book to market equity stocks compared to big and lower book to market equity stocks (Drew and Veeraraghavan, 2002). Drew, Naughton, and Veeraraghavan (2003) conducted studies on FamaFrench three-factor model for Hong Kong, Korea, Malaysia, and the Philippines and the result found was in favor of the Fama French three-factor model. Though the Fama-French sector showed positive results in western and developed economies more precisely, the model is not well-developed in developing nations like Bangladesh. In Bangladesh, Dhaka Stock Exchange is 
one of the oldest and largest emerging frontier stock markets in the South Asian region (Islam and Khaled, 2005). It was interesting to see up surging trend in Dhaka Stock Exchange even though the world was going through the global financial crisis in 2008 (Mollik and Bepari, 2011).

Mobarek and Mollah (2005) conducted a study with 123 non-banking firms listed on the Dhaka Stock Exchange. This study didn't find any encouraging resultsin favor of the CAPM Model. Rahman and Baten (2006) explained that excess market return, market size, and book to market ratio are significant in explaining the return of any stock. In Bangladesh too, few studies have been conducted regarding stock return with CAPM and Fama French Factor. The result is a mixed one.

The stock market of any country is at the heart of industrialization (Sattar, 2017). Numbers of studies have been conducted on the CAPM model and Fama French three-factor model in developed countries, however, there's been limited studies conducted in developing countries like Bangladesh (Sattar, 2017). The nature of market characteristics and investor behavior shapes if the same theories which are successful in developed countries will be successful in developing ones (Sattar, 2017). Since inception in 1954, the Dhaka Stock Exchange has been growing steadily in line with a steady GDP Growth rate of over 6\% per annum (Sattar, 2017). However, the Dhaka Stock Exchange market didn't get much attention from the researchers. Rahman et al. conducted a study over the period 1999 and 2003, and he found out that the Fama French model can explain better regardless of market efficiency in Dhaka Stock Exchange (Sattar, 2017; Rahman, Baten, Uddin, \&Zubayer, 2006).

For that, there's a research gap to explore the efficiency and effectiveness of both the CAPM model and the Fama French three-factor model. This study captures all listed cement manufacturing companies in Dhaka Stock Exchange. Due to urbanization and massive construction activities, the cement industry has been reaping the benefits of steady growth. According to Nayan (2013), the cement industry is more likely to maintain steady growth over time, too (Sattar, 2017). For that, this study will help practitioners to understand if the CAPM Model and Fama French three-factor can explain stock's expected return on the Dhaka Stock Exchange.

\section{METHOD}

\section{a) Sample and Data}

The samples were collected from the monthly closing stock prices of all listed cement manufacturing companies in the Dhaka Stock Exchange from April 2013 to August 2019. There are 7 listed cement manufacturing companies in Dhaka Stock Exchange. For calculating the market return, both DSEX and DS30 were followed in this study. A total of 77 samples were considered for this study. 30 Day BB Bill was taken as a proxy for the risk-free rate (2.96\%).

\section{b) Construction of Portfolio}

We have used seven stocks of Cement Manufacturing companies, which are listed on the Dhaka Stock Exchange. Returns of these stocks have been used as dependent variables for the study. Excess return over risk-free return has been calculated as the dependent variable for this study. Four portfolios have been constructed using different combinations of firm size and book to equity ratio. The size of the firm is calculated using the market capitalization of the firms. Then, the first four firms (Lafarge, Heidelberg, M.I., and Confidence) are considered as Big sized firms whereas the last three firms (Premier, Meghna, Aramit) are considered as Small-sized firms. On the other hand, Book value is the difference between total assets and total liabilities. Firms with higher Book to Market value ratio are called value firms and firms with the lower market to book value ratio are called growth firms. Also, market value is the market capitalization of the firms. First, four firms (M.I, Premier, Meghna, Confidence) are considered as value firms while the last three firms (Aramit, Lafarge, Heidelberg) have been considered for this study. As a result, four portfolios have been created such as Big sized and Growth firms (BG), Big sized and value firms (BV), Small sized and Growth firms (SG) and Small sized and value firms (SV).

\section{c) Defining variables}

The excess portfolio return is taken as the dependent variable in all cases. The equally-weighted average return for each portfolio is calculated after deducting a risk-free rate from average monthly portfolio returns. For the CAPM model, the only independent variable is the market risk premium. In the case of the Fama French three-factor model, two more independent factors are added, namely size risk premium, and book to market (BM) risk premium. For calculating the market return, we have considered two scenarios separately: DSEX, and DS30. The size risk premium is calculated through the calculation of differences in average return between the portfolio of four big sized firms and three small-sized firms and it is represented as SMB (Small minus Big). HML (High minus Low) represents the book to market value risk premium and it's calculated through differences in average return between the top four firms and lowest three firms.

\section{d) The Model}

As discussed, we have examined the evidence for two indexes separately: DSEX and DS30. In the case of the CAPM model, we followed this model:

$$
R_{p t}-R_{f}=\alpha_{p t}+\beta_{p}\left(R_{m t}-R_{f}\right) \varepsilon_{p t}
$$


If the model describes the expected return, $\alpha_{p t}$ should be equal to zero and $\beta_{p}$ should be more than one.

$$
R_{p t}-R_{f}=\alpha_{p t}+\beta_{p}\left(R_{m t}-R_{f}\right)+s_{p}(S M B)+h_{p}(H M L)+\varepsilon_{p t}
$$

The study aims to find out among market, size and value premium, which factors have a maximum impact on the model.

\section{Results}

a) CAPM Mode/ with Dsex

Table 1: Regression Statistics of CAPM Model under DSEX

\begin{tabular}{|c|c|}
\hline \multicolumn{2}{|c|}{ Regression Statistics } \\
\hline Multiple R & 0.773922376 \\
\hline R Square & 0.598955844 \\
\hline Adjusted R Square & 0.593608588 \\
\hline Standard Error & 0.042684473 \\
\hline Observations & 77 \\
\hline
\end{tabular}

The study included 77 monthly returns. model explains around $59.36 \%$ of the factors under the Adjusted $\mathrm{R}$ square is around $59.36 \%$, so the CAPM DSEX index.

Table 2: Coefficients and P-value of CAPM under DSEX

\begin{tabular}{|c|c|c|c|c|}
\hline & Coefficients & Standard Error & t Stat & P-value \\
\hline Intercept & -0.002630421 & 0.005379772 & -0.488946485 & 0.626306 \\
\hline rm-rf (DSEX) & 1.041091172 & 0.098368676 & 10.58356396 & $1.55 \mathrm{E}-16$ \\
\hline
\end{tabular}

The beta coefficient (rm-rf) is more than 1 market risk premium has no significant impact on the (1.04). Here, the $p$-value is 0.62 , so under 0.01 confidence level, the null hypothesis is rejected that cross-sectional stock market returns.

b) CAPM Modewith Ds30

Table 3: Regression Statistics of CAPM Model under DS30

\begin{tabular}{|c|c|}
\hline \multicolumn{2}{|c|}{ Regression Statistics } \\
\hline Multiple R & 0.773550007 \\
\hline R Square & 0.598379613 \\
\hline Adjusted R Square & 0.593024675 \\
\hline Standard Error & 0.042715127 \\
\hline Observations & 77 \\
\hline
\end{tabular}

The study included 77 monthly returns. model explains around $59.30 \%$ of the factors under the Adjusted $\mathrm{R}$ square is around $59.30 \%$, so the CAPM DS30 index.

Table 4: Coefficients and P-value of CAPM under DS30

\begin{tabular}{|c|c|c|c|c|}
\hline & Coefficients & Standard Error & $t$ Stat & P-value \\
\hline Intercept & -0.002874522 & 0.005374 & -0.53487 & 0.594325 \\
\hline rm-rf (DS30) & 1.002543619 & 0.09484 & 10.57088 & $1.64 \mathrm{E}-16$ \\
\hline
\end{tabular}

Here, the p-value is 0.59 , so under 0.01 confidence level, the null hypothesis is rejected that market risk premium has a significant impact on the cross-sectional stock market returns. 
c) Fama French three-factor model under DSEX

Table 5: Regression of the Fama French three-factor Model under DSEX

\begin{tabular}{|c|c|}
\hline \multicolumn{2}{|c|}{ Regression Statistics } \\
\hline Multiple R & 0.799718974 \\
\hline R Square & 0.639550437 \\
\hline Adjusted R Square & 0.624737441 \\
\hline Standard Error & 0.041017131 \\
\hline Observations & 77 \\
\hline
\end{tabular}

Adjusted $\mathrm{R}$ square is $62.47 \%$ which shows that explanatory power compared to the CAPM model for the Fama French three-factor model has better DSEX.

Table 6: Coefficients and P-value of Fama French under DSEX

\begin{tabular}{|c|c|c|c|c|}
\hline & Coefficients & Standard Error & t Stat & P-value \\
\hline Intercept & -0.002302226 & 0.005171 & -0.4452 & 0.65749 \\
\hline Rm-rf & 0.994040159 & 0.095941 & 10.36091 & $5.51 \mathrm{E}-16$ \\
\hline S-B & 0.164898415 & 0.066662 & 2.473661 & 0.0157 \\
\hline H-L & -0.128447129 & 0.068521 & -1.87456 & 0.064854 \\
\hline
\end{tabular}

Intercept and beta for value risk premium $(\mathrm{H}-\mathrm{L})$ are negative, though market risk premium yields more positive. Under 0.01 confidence level, size risk premium and value risk premium can't be rejected and they have

d) Fama French three-factor model under DS30

Table 7: Regression of Fama French three-factor under DS30

\begin{tabular}{|c|c|}
\hline \multicolumn{2}{|c|}{ Regression Statistics } \\
\hline Multiple R & 0.809924692 \\
\hline R Square & 0.655978007 \\
\hline Adjusted R Square & 0.641840117 \\
\hline Standard Error & 0.040071549 \\
\hline Observations & 77 \\
\hline
\end{tabular}

Adjusted $\mathrm{R}$ square is $64.18 \%$, so it has around $64.18 \%$ explanatory power for the Fama French threefactor model in the case of the DS30 index.

Table 8: Coefficients and P-value of Fama French under DS30

\begin{tabular}{|c|c|c|c|c|}
\hline & Coefficients & Standard Error & t Stat & P-value \\
\hline Intercept & -0.001998755 & 0.005050408 & -0.39576106 & 0.693435597 \\
\hline Rm-rf & 0.969453991 & 0.090026937 & 10.76848801 & $9.88562 \mathrm{E}-17$ \\
\hline S-B & 0.216577499 & 0.064594848 & 3.352860276 & 0.001270228 \\
\hline H-L & -0.105046709 & 0.067211098 & -1.562936953 & 0.122392456 \\
\hline
\end{tabular}

Intercept and beta for value risk premium $(\mathrm{H}-\mathrm{L})$ are negative, though market risk premium yields more positive. Under the 0.01 confidence level, value risk premium can't be rejected and it has significant explanatory power in describing returns of the portfolio. On the other hand, market risk premium and size risk premium are rejected under 0.01 confidence level. significant explanatory power in describing returns of the portfolio. On the other hand, the market risk premium is rejected under 0.01 confidence level.

\section{Discussion}

The basic underlying assumption is that the Fama French three-factor model has better explanatory power compared to CAPM Model. The empirical evidence on cement manufacturing companies listed in the Dhaka Stock Exchange also shows the same evidence. CAPM Model under both DSEX and DS30 has 
explanatory power or R Square around 59\%. In the case of the Fama French three-factor model, the explanatory power increases to around 65\% under both DSEX and DS30. However, it is interesting to see that DS30 explains better compared to DSEX. Upon discussing both CAPM and Fama French three-factor model, it's well-observed that the Fama French three-factor model has better explanatory power compared to the CAPM model. The four models under two indexes (DSEX and DS30) explain $58-65 \%$ in the range of the total factors in the model. Moreover, the Null hypothesis is rejected for the CAPM model for both indexes. On the other hand, the null hypothesis for the market risk premium in the case of Fama French three-factor under DSEX is rejected and the other two null hypotheses (size and value risk premium) can't be rejected. For the DS30 Fama French three-factor model, the null hypothesis for market risk premium and size risk premium are rejected and the null hypothesis for size risk premium can't be rejected. As a matter of fact, it can be stated that these two models yield a mixed result. However, the Fama French three-factor model has better explanatory power compared to CAPM Model.

\section{Conclusion}

This paper aims to analyze excess return on the portfolio by both the CAPM model and the Fama French three-factor model and then describe the effectiveness of both these models. For Fama French three-factor analysis, three risks have been taken into consideration such as market risk premium, size risk premium, and book to the market value risk premium. The result shows that the Fama French three-factor model has better explanatory power compared to CAPM Model. The study is based on monthly returns from April 2013 to August 2019. Four portfolios have been constructed. This study reveals that market risk premium beta for the cement industry in Dhaka Stock Exchange is close to 1, which has an almost perfect linear relationship. The result is in line with the basic assumption in developed nations that Fama French three-factor model can explain better compared to the CAPM model as the model is more complex and requires more data input. This paper provides more opportunities for future research for exploring more studies on the effectiveness of both these models for the investors of Bangladesh.

\section{References Références Referencias}

1. Black, F. S; Jensen, M. C; \& Scholes, M. S. (1972). The Capital Asset Pricing Model: Some Empirical Tests, Michael C. Jensen, edn, Praeger Publishers Inc., Studies in the Theory of Capital Markets.

2. Chowdhury, E. (2017). Functioning of Fama-French Three-Factor Model in Emerging Stock Markets: An Empirical Study on Chittagong Stock Exchange,
Bangladesh. Journal of Financial Risk Management, 06(04), pp. 352 -363.

3. D. Blake, Financial market analysis, 2nd ed. (Wiley, West Sussex, England, 2000).

4. Fama, E. \& French, K. (1993). Common risk factors in the returns on stocks and bonds Journal of financial Economics, 33, 3-56.

5. Fama, E. F., \& Mac Beth, J. D. (1973). Risk, return, and equilibrium: Empirical tests. The Journal of Political Economy, 607-636.

6. Isakov, Dušan. (1999). Is Beta Still Alive? Conclusive Evidence from the Swiss Stock Market. European Journal of Finance. 5. 202-212. 10.1080/135184 799337046.

7. J. Toporowski, The end of finance: Capital market inflation, financial derivatives and pension fund capitalism. (Routledge, London, 2000).

8. Lintner, J. (1965). The valuation of risk assets and the selection of risky investments in stock portfolios and capiatal budgets Review of Economics and Statistics, 47, 12-37.

9. R. Faff, Financial Review 36(4), 157-174 (2001).

10. Reinganum, M. R. (1981). Misspecification of capital asset pricing: Empirical anomalies

11. based on earnings' yields and market values. Journal of financial Economics, 9(1), 19-46.

12. Sattar, M. (2017). CAPM Vs Fama-French ThreeFactor Model: An Evaluation of Effectiveness in Explaining Excess Return in Dhaka Stock Exchange. International Journal of Business and Management, 12(5), p.119.

13. Sayeed, Mohammad Abu and Khatun, Mahfuza and Chowdhury, Biplob, Does Fama-French Three Factor Model Outweigh the CAPM Model? Evidence from the Dhaka Stock Exchange (December 20, 2014). Available at SSRN: https://ssrn.com/a bstract $=2636131$ or http://dx.doi.org/10.2139/s srn.2636131

14. Sharpe, W. (1964). Capital asset prices: a theory of market equilibrium under conditions of risk. Journal of Finance, 19, 425-442. 